\title{
Adoption and Efficacy of ISO 15189 in Medical Laboratories for Diagnostic and Research
}

\author{
Man-Gil Yang ${ }^{1}$, Won Ho Lee 2,3 , and Jin Hyun Jun ${ }^{3,4}$ \\ ${ }^{1}$ Biomedical Institute, Seoul National University Hospital, Seoul 03080, Korea \\ ${ }^{2}$ Department of Laboratory Medicine, KyungHee University Medical Center, Seoul 02447, Korea \\ ${ }^{3}$ Department of Biomedical Laboratory Science, Graduate School, Eulji University, Seongnam 13135, Korea \\ ${ }^{4}$ Department of BK21 Senior Healthcare, Graduate School, Eulji University, Seongnam 13135, Korea
}

\section{메디컬시험기관에서 ISO 15189 도입의 필요성과 시행의 효용성}

\author{
양만길 ${ }^{1}$, 이원호 ${ }^{2,3}$, 전진현 3,4 \\ ${ }^{1}$ 서울대학교병원 의생명연구원, ${ }^{2}$ 경희대학교의료원 진단검사의학과, ${ }^{3}$ 을지대학교대학원 임상병리학과, ${ }^{4}$ 을지대학교대학원 BK21 시니어헬스케어학과
}

\begin{abstract}
The requirements for medical laboratories ISO 15189 is examined in organization and a quality management system, stressing the importance of evidence, document control, and control of records and clinical material. Medical services are provided from the areas of resource management, and pre-examination, examination and post-examination processes. The main goal of ISO 15189 accreditation is to improve the quality of laboratory services provided for patients and clinical users not only through compliance with consensually developed and harmonized requirements but also by adopting the philosophy of continual improvement using the Plan-Do-Check-Act cycle. Laboratory quality should be evaluated and improved in all steps of the testing process as the state-of-the art indicates that the pre- and post-analytical phases are more vulnerable to errors than the intra-analytical phase. The Korea Laboratory Accreditation Scheme (KOLAS), a national accreditation body, provides medical laboratory accreditations for appropriate approaches to evaluating the competence of a medical laboratory in providing effective services to its customers and clinical users. Adoption of ISO 15189 in 2010 s as a government policy has been delayed, and only 5 laboratories have been accredited to date in Korea. The medical laboratories should seek the adoption of ISO 15189 with a positive attitude for quality improvement and strengthening of international competitiveness.
\end{abstract}

Keywords: ISO 15189, Medical laboratory, Quality improvement, KOLAS, International competitiveness
This is an Open Access article distributed under the terms of the Creative Commons Attribution Non-Commercial Licens (http://creativecommons.org/licenses/by-nc/4.0) which permits unrestricted non-commercial use, distribution, and reproduction in any medium, provided the original work is properly cited.

Copyright ( 2016 The Korean Society for Clinical Laboratory Science. All rights reserved.
Corresponding author: Jin Hyun Jun Department of Biomedical Laboratory Science, Eulji University, 553 Sanseong-daero, Sujeong-gu, Seongnam 13135, Korea Tel: $82-31-740-7210$ Fax: 82-31-740-7354

E-mail: junjh55@hanmail.net

Received: May 9, 2016 Revised: May 12, 2016 Accepted: May 14, 2016

\section{서 론}

국제 표준화 기구(International Organization for Standardization, ISO) 또는 ISO는 여러 나라의 표준 제정 단체들의 대 표들로 이루어진 국제적인 표준화 기구이다[1]. 스위스 제네바에 본부를 두고 있는 단체로서 1947년에 출범하였으며 나라마다 다
른 산업, 통상 표준의 문제점을 해결하고 공업 상품이나 서비스의 국제 교류를 용이하게 하기 위해 국제적으로 통용되는 표준을 개발 하고 보급하는 단체이다. ISO 회원국으로(2016년 3월 기준) 정회 원 11 개국, 준회원 38 개국, 간행물구독회원 4 개국 등 총 161 개국 이 가입하여 활동하고 있다[2]. ISO 가이드에서 표준화란 '일상적 이고 반복적으로 일어나는 실제 문제 또는 가능성이 있는 문제에 
대해 주어진 여건 하에서 최적의 질서를 달성하기 위한 목적을 확 립하기 위한 일련의 활동'이라고 규정하고 있다[3].

표준화에 필요한 기본적인 품질경영 시스템에 대한 국제품질보 증제도인 ISO 9000 시리즈는 제품의 생산 및 유통과정 전반에 걸 쳐 국제규격을 제정한 소비자 중심의 품질보증제도이다[4]. 세계 최초의 품질인증제도 도입은 1976년 영국의 품질인증기관인 영국 표준협회(British Standard Institution)의 발의로 1987년 모든 산 업에서 시행되었다. 이러한 품질인증제도에 대한 국제적인 공신력 이 향상됨에 따라 국내제품의 해외 수출 시 국제적인 표준화 시스 템인 ISO 9000 의 인증을 요구하는 사례가 늘어나자 우리나라의 공 업진흥청(현 중소기업청)은 ISO 9000 시리즈를 KS (Korea Industrial Standard)규격에 채택하고 인증기관을 지정해 1993년 부터 시행하고 있다. ISO 9000은 단순히 제품의 품질규격 합격여 부만을 확인하는 일반품질인증과는 달리 해당제품이나 서비스의 설계에서부터 생산시설, 시험검사, 애프터서비스 등 전반에 걸쳐 규격준수 여부를 확인하고 이를 인증해 주는 제도이다[5-7]. 그 중 에서 ISO 9001은 제품의 디자인 및 개발과 생산, 서비스 등을 내용 으로 하는 가장 광범한 적용범위를 가진 품질경영시스템에 대한 규 격이다[8].

이러한 ISO에서 표준화에 필요한 품질경영시스템이란 제품의 설계, 개발, 생산, 설치 및 서비스까지의 모든 기업 활동을 체계적이 고 효율적으로 관리하여 고객만족도의 향상과 효율적인 경영을 추 구하는 시스템이다. 전 세계의 모든 기업마다 각기 달리 운영되던 품질 관리 방법 및 시스템을 국제적으로 통일하여 무역 교류의 촉 진과 국제 경쟁력을 강화하는데 이용되고 있다. 또한, 품질 생산 과 정에서의 불합리한 요소의 제거, 책임과 권한의 강화, 문서화와 투 명화, 지속적 개선 등을 통해 생산성을 높이고 고객만족도를 향상 시킬 수 있다. 근래에는 유형의 제품을 생산하는 제조업과 무형의 서비스 산업뿐만 아니라 의료 및 연구 분야에도 ISO 품질경영시스 템의 적용이 확대되고 있다[9,10].

다양한 분야에 대한 품질표준들 중에서 메디컬시험기관에 대한 품질 및 적격성에 대한 요구사항인 ISO 15189는 ISO 9001; 품질 경영시스템-요구사항과 ISO/IEC 17025; 시험기관 및 교정기관의 능력에 관한 일반요구사항인 두 표준을 바탕으로 2003년에 제정 되었다[11]. 따라서 ISO 15189는 기본적으로 위의 두 표준에서 요 구하는 사항을 따르며, 메디컬시험기관에 요구되는 사항들을 충족 하고 있다. 그러므로 ISO 15189를 충족한다는 의미는 ISO 9001 과 ISO/IEC 17025에서 규정하는 요구사항을 모두 충족하고 있음을 의미한다. 이렇게 제정된 ISO 15189 는 메디컬시험기관 자체에서 또는 시험기관의 고객, 규제당국, 및 인정기관에서 메디컬시험기 관의 품질경영시스템 개발 및 적격성을 평가하고 확인 또는 인정을
위한 목적으로 사용될 수 있으나 메디컬시험기관 인증을 위한 목적 으로는 사용하지 않도록 고지하고 있다. 본 표준은 시험기관의 기 술적 적격성을 평가하는 ISO/IEC 17025 표준 문서를 기초로 $\mathrm{ISO} / \mathrm{CASCO}$ 에서 메디컬시험기관의 품질 보증의 중요성이 강조되 면서 ISO/TC 212에서 2003년 메디컬시험기관의 능력에 관한 특 수 요구사항을 규정하였다. 우리나라에서는 2003년 제1판 KS P ISO 15189:2005가 제정되었고, 메디컬시험기관의 특성을 고려하 여 2007년 제2판 KS P ISO 15189:2011을 거쳐, 2012년에는 제3 판 KS P ISO 15189:2013으로 개정되었다[12]. 또한 이 표준은 의 료서비스에 대해 국제적으로 인정받을 수 있는 품질보증에 대한 기 준을 설정하여 국가 간 기술장벽을 제거하고 상호 인정할 수 있는 여건을 조성하여 세계시장에서 공급자와 수요자 모두에게 품질에 대한 신뢰감을 제공하는 것을 목적으로 한다. 본 논고에서는 이러 한 메디컬시험기관에 대한 품질 및 적격성에 대한 요구사항인 ISO 15189 의 특징을 살펴보고, 이에 대한 필요성과 시행에 따른 효용 성에 대한 이해도를 높이기 위해 주요 사항들을 기술하고자 한다.

\section{본 론}

\section{1. 메디컬시험기관에 대한 ISO 15189의 특징}

메디컬시험기관 인정제도는 법률 또는 국제기준에 적합한 인정 기구가 전문적인 자격을 갖춘 평가사로 하여금 메디컬시험기관의 품질 시스템과 기술능력을 평가하도록 하여 메디컬시험분야에 대 한 시험능력이 있다는 것을 공식적으로 인정하는 제도이다[12]. ISO 15189는 메디컬시험기관의 서비스의 품질 및 역량을 입증하 는데 필수적인 요구사항을 포함하고 있고, 게다가 표준에 알려진 대로 기술적으로 유효한 시험 혹은 검사 결과를 일관성 있게 제공 하고 있다. ISO 15189는 의학계, 과학계 및 임상 분야 커뮤니티의 강력한 참여에 의해 제정된 것으로, 메디컬시험기관은 품질경영시 스템을 개발하고 기관 자체의 역량을 유지하는데 활용할 수 있고 인정기구는 인정을 통해 이러한 시험기관들의 역량을 확인하거나 승인하는데 사용할 수 있다. ISO 15189 인정은 역량, 공정성 및 일 관성을 결정하기 위해 시험기관에 대한 독립적인 평가를 진행한다. 이 표준에는 메디컬시험기관 검사에 관여하는 실무자의 자격 및 지 속적인 역량, 시험기관 규모, 장비, 시약 및 소모품, 분석 전 및 분석 인자, 품질보증을 위한 고려사항 및 분석 후 인자 등이 기술되어 있 다[12].

인정과정에서는 업무와 관련된 범주에 전문성을 갖춘 전문가 및 임상 평가사들은 다음의 사항을 포함하여 시험데이터 산출에 영향 을 미치는 시험기관에서의 모든 요인에 대한 철저한 평가를 수행한다.

a) 직원의 기술적 역량 
b) 샘플 취합 및 보고 등과 같이 분석 전/후 요소를 포함한 시험방 법의 유효성 및 적절성

c) 환자 구분, 샘플 무결성을 유지하기 위한 처리 및 운송을 포함 한 샘플 질 관리

d) 이전의 환자 기록결과와 알려진 임상진단과 관련된 이력 검토

e) 특정 질환에 대한 전문화된 시험센터와 같이 '위탁 시험기관' 의 활용과 관련된 절차

f) 관련 표준에 대한 교정 및 측정의 소급성

$\mathrm{g}$ ) 시험장비의 적절성 및 교정, 유지 시험 환경

h) 시험데이터의 품질 보증

i) 수용 가능한 소요 시간

j) 적절한 윤리적 가치의 적용

ISO 15189는 ISO/IEC 17025 (시험 및 교정기관의 역량에 대한 일반 요구사항)와 ISO 9001 (품질경영시스템-요구사항)에 기반하 였다. 그러므로, 이 표준은 시험기관의 일반 요구사항뿐만 아니라, ISO 9001 인증에 기술된 품질시스템 요소가 통합되어 있다. ISO 15189 에 대한 인정은 메디컬시험기관에 대한 5 가지의 주요 추가 기준을 제시한다.

a) 필요 할 수도 있는 시험유형 및 샘플타입에 대한 조언 제공 여부

b) 기관 서비스의 품질을 위한 테스팅을 위해서 환자샘플을 참고 하는 임상의와 협력하는 책임을 기관에 부여함으로써 임상 직원과의 상호관계 유지 여부

c) 진단 및 환자 관리와 관련된 시험결과에 대한 의견 제공 여부

d) 샘플 취합 혹은 취합하지 않았을 시, 취합절차, 샘플 용기 및 샘플양에 대한 정보에 대한 제공 여부

e) 윤리실천 - 첫 번째 의무는 '고객'에게 아닌 환자에게 있다 지속적으로 기준을 준수하고 있음을 보장하기 위해, 공인 기관 들은 관련 표준에 의거하여 기술적인 전문성을 유지하고 있는지 여 부를 점검하기 위해 정기적으로 갱신 평가를 받고 있다. 이러한 기 관들은 또한 기관의 역량에 대한 하나의 지속적인 검증으로서 정기 적인 숙련도시험프로그램인 외부정도관리 프로그램에 참여할 것 을 요구 받고 있다[12].

\section{2. 메디컬시험기관의 조직 구성과 품질경영시스템}

경영시스템 중에서 조직은 '책임, 권한 및 상호관계가 정해져 있 는 사람들 및 시설의 모임'이라 정의되어 있다(ISO 9000 3.3.1). 이 표준에서는 병원의 일부를 구성하고 있는 메디컬시험기관을 나타 내는데, 운영상황에 따라서 병원이나 검사센터 그 자체를 의미하기 도 한다. 그리고 조직 구조는 사람들의 책임, 권한 및 상호관계의 배 치를 의미하며 일반적으로는 조직도로 표현되고 있다. 일반적으로 병원의 최고책임자는 병원장이 되고, 그 산하에는 행정부, 진료부, 간호부 등이 주요 부서로 편성되어 있으며, ISO 15189 시스템의 대 상이 되는 메디컬시험기관인 진단검사의학과, 병리과, 핵의학과 등은 진료부의 산하조직이다. 진단검사의학과는 업무 분야에 따라 임상화학, 임상미생물, 진단혈액, 진단면역, 수혈의학, 분자유전 등 으로 구분할 수 있다. 2012년에 개정된 KS P ISO 15189:2013에서 의 메디컬시험에 대한 인정 분야는 진단검사의학, 핵의학, 병리학 등 3 개 분야, 각 분야의 검사 및 진단 업무를 세분하여 17 개 소분류 로 구분하고 있다(Table 1).

메디컬시험기관은 일반적으로 병원 또는 검사센터와 같은 큰 조 직의 일부인 경우가 많다. 병원 안의 검사부라는 일부의 부문이거 나 회사조직 안의 일부 사업부일 수도 있다. 메디컬시험기관이 적 합성 평가를 신청할 수 있는 기관으로서 인정 대상이 되기 위해서 는, 검사활동에서 독립성을 가지며 조직 내의 타 부문 또는 상위 조 직 혹은 관련 조직에서의 영향이 배제되어야만 가능하다. 품질경영 시스템은 '품질에 관하여 조직을 지휘하고, 관리하기 위하여 방침 및 목표를 설정하고 그 목표를 달성하기 위한 상호 관련된 또는 상 호 작용하는 요소의 집합'이라고 정의된다. 품질경영시스템의 프 로세스는 계획수립(Plan), 실행(Do), 평가(Check) 및 조치(Act)와 지속적 개선(Improvement)으로 구성되며(Fig. 1), 메디컬시험기 관의 품질경영시스템은 임상의 또는 환자의 니즈 및 요구사항을 충 족시켜야 한다.

품질경영시스템을 기획할 때는 요구사항을 준수하고 품질목표 를 충족시켜야 하며 변경하고자 하는 경우에는 품질경영시스템의 통합성을 유지시켜야한다. 품질경영시스템의 통합성은 목표 달성 을 위한 세부 요소들의 상호작용 즉, Plan-Do-Check-Act

Table 1. List of parts and tests for KS P ISO 15189:2013

\begin{tabular}{cllll}
\hline \multicolumn{1}{c}{ 대분류 } & \multicolumn{3}{c}{ 중분류 } \\
\hline 1. 진단검사의학 & 1.01_진단혈액학검사 & 1.02_분자유전학검사 & 1.03_세포유전검사 & 1.04_임상화학검사 \\
& 1.05_미생물검사 & 1.06_조직적합성검사 & 1.07_유세포검사 & 1.08_진단면역검사 \\
& 1.09_요검사 & 1.10_수혈의학검사 & & 2.04_기타외검사 \\
2. 핵의학 & 2.01_호르몬검사 & 2.02_종양표지자검사 & 2.03_간염검사 & \\
3. 병리학 & 3.01_조직병리진단 & 3.02_세포병리진단 & 3.03_특수병리진단 & \\
\hline
\end{tabular}




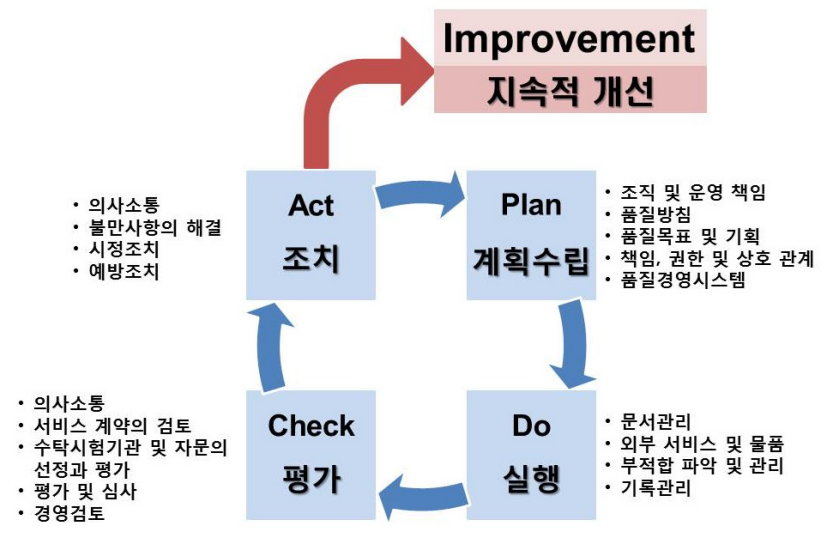

Fig. 1. P-D-C-A-I cycle in quality management sysem in ISO 9001.

(P-D-C-A) cycle이 서로 유기적으로 작용하여 지속적인 개선 (improvement)이 이루어짐을 의미한다(Fig. 2).

\section{3. 메디컬시험기관의 품질경영시스템을 위한 문서화 및 문서관리}

품질경영시스템 문서화작업에 포함되어야 할 요소로 품질방침 및 품질목표, 품질매뉴얼, 절차 및 기록 등을 요구하고 있다. 품질방 침이란 해당 조직의 최고경영자에 의하여 공식적으로 표명된 품질 에 관한 조직의 전반적인 의도 및 방향을 의미하며, 조직의 전체 경 영방침과 연계성이 있는 상태에서 고객 만족의 기대 수준 및 달성 가능성, 지속적 개선에 대한 영역과 중요도, 시급성, 효과 정도, 조 직이 사용할 수 있는 자원의 한계성 등을 고려하여 결정하여야 한 다. 품질 목표는 조직의 품질방침에 근거를 두어야 하며 품질목표 는 조직의 계층별로 설정되고 그 설정된 품질목표는 운영 측면에서 정량적 수치화, 계수화 되어야 한다. 품질매뉴얼은 품질경영시스 템의 전반적인 방향을 규정하고 품질경영시스템의 이행과 유지 등 에 필요한 기본적인 사항들인 품질 경영 시스템상의 업무분장, 책 임과 권한, 품질경영 시스템상의 요소별 절차 및 관리방법 등에 관 한 사항들을 기술한 문서를 말한다. 품질매뉴얼의 하부 문서들로 세부절차서, 지침서, 각종 기록물 등이 있을 수 있다(Fig. 2). 작성된 문서는 하드카피 또는 전자기록 등을 비롯해 디지털, 아날로그, 사 진 또는 손으로 쓰는 것을 포함하여 어떠한 종류의 매체도 사용 가 능하다. 또한 쉽게 검색이 가능해야 하며 승인되지 않은 변경이나 부당한 훼손이 있어서는 안 된다.

메디컬시험기관에서 ISO 15189에 준하여 작성된 표준문서(매 뉴얼, 절차서, 지침서) 목록의 예를 Table 2에 나타내었다. 이렇게 작성된 문서들은 ISO 품질관리시스템에서 문서관리에 기술된 요 구사항에 따라 관리되어야 한다. ISO 15189의 요구사항을 그대로 매뉴얼로 삼고 있는 메디컬시험기관도 볼 수 있지만 적어도 각 요 구사항에 대응하여 $5 \mathrm{~W} 1 \mathrm{H}$ 형태로 기술한다. 즉, 표준은 어떤 조직

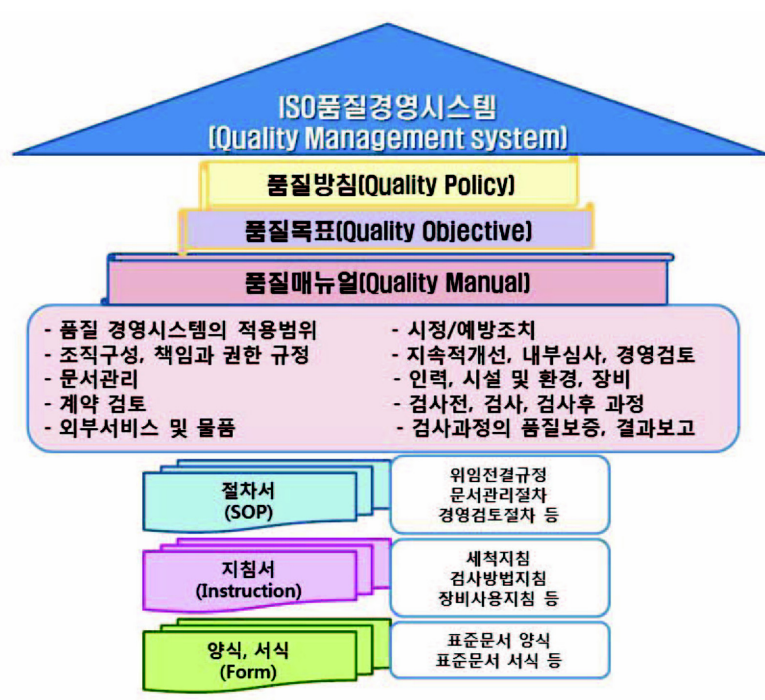

Fig. 2. Requirements of documentations in ISO.

에서든 적용할 수 있도록 일반형으로 쓰여 있으므로 이를 바탕으로 해당 기관은 $5 \mathrm{~W} 1 \mathrm{H}$ 로 방침을 나타낼 필요가 있다. 상세한 how의 내용은 절차서를 인용할 수도 있지만 가능한 불필요한 문서의 수는 줄여야 한다. 시험방법의 절차서는 매뉴얼과 하나로 하지 않고 별 도 작성하는 것이 보통이다.

문서관리는 ISO 15189 의 가장 핵심적인 요구사항이기도 하다. 메디컬시험기관은 유효하지 않은 문서의 부주의한 사용 방지를 위 하여 문서관리에 주의를 기울여야 한다. 이를 위해서 메디컬시험기 관은 문서관리 절차를 갖추어야 한다. 관리가 필요한 문서라 하면 발행 판의 변경 또는 일정시간의 경과에 따라 바뀔 수 있는 문서이 며 방침선언서, 사용설명서, 흐름도, 절차, 시방서, 양식, 보정표, 생 물학적 참고 범위 및 그출처, 도표, 포스터, 통지서, 규약, 소프트웨 어 문서화, 도면, 계획서, 계약서와 시험절차를 준용한 규정, 표준 및 교과서와 같은 외부 출처 문서가 포함된다. 이것들은 하드카피 또는 전자기록 등 다양한 매체에 상관없고 디지털, 아날로그, 사진 또는 손으로 쓰는 것이어도 좋다. 관리문서란 표준의 요구사항(문 서 대장에 등록, 최신판을 유지, 개폐 절차에 따름, 정기적으로 재검 토, 등)에 따라 관리하는 문서를 가리키며 비관리문서는 그 대상이 아닌 문서를 가리킨다. 조직 내의 직원이 문서를 입수하였을 때, 예 를 들면 표지에 붉은 글자로 비관리문서 등의 식별기호를 붙여서 관리문서인지 비관리문서인지 알 수 있도록 해 두어야 한다. 메디 컬시험기관의 경우, 표준지침서(standard operating procedure, $\mathrm{SOP})$ 의 중요점을 요약한 간이 지침서 또는 검사흐름도 등을 현장 에서 작성하는 일이 많은데, 그렇게 해서 작성된 문서는 종종 $\mathrm{SOP}$ 가 개정되었을 때에 개정되지 않는 경우가 있어서 중대한 사고로 이어질 우려가 있으므로 반드시 관리문서에 포함해야 한다. 
Table 2. List of standard documents in ISO 15189

\begin{tabular}{|c|c|c|c|c|c|}
\hline \multicolumn{2}{|c|}{ 매뉴얼 } & \multicolumn{2}{|r|}{ 절차서 } & \multicolumn{2}{|r|}{ 지침서 } \\
\hline MLQM-01 & 일반사항 & & & & \\
\hline \multirow[t]{15}{*}{ MLQM-02 } & 경영사항 & MLQP-01 & 1. 조직 및 운영 책임 & & \\
\hline & & MLQP-02 & 2. 품질경영시스템 & & \\
\hline & & MLQP-03 & 3. 문서 관리 & & \\
\hline & & MLQP-04 & 4. 서비스 계약 & MLQI-001 & 검사 종목 및 방법 \\
\hline & & MLQP-05 & 5. 수탁 시험기관에 의한 검사 & & \\
\hline & & MLQP-06 & 6. 외부 서비스 및 물품 & & \\
\hline & & MLQP-07 & 7. 자문 서비스 & & \\
\hline & & MLQP-08 & 8. 불만 사항의 해결 & & \\
\hline & & MLQP-09 & 9. 부적합의 파악 및 관리 & & \\
\hline & & MLQP-10 & 10. 시정조치 & & \\
\hline & & MLQP-11 & 11. 예방조치 & & \\
\hline & & MLQP-12 & 12. 지속적 개선 & & \\
\hline & & MLQP-13 & 13. 기록관리 & & \\
\hline & & MLQP-14 & 14. 평가 및 심사 & & \\
\hline & & MLQP-15 & 15. 경영검토 & & \\
\hline \multirow[t]{27}{*}{ MLQM-03 } & 기술사항 & MLQP-16 & 인력 & MLQI-002 & 직원자격부여 및 적격성 평가 \\
\hline & & & & MLQI-003 & 직무기술서 \\
\hline & & & & MLQI-004 & 신입직원오리엔테이션 \\
\hline & & & & MLQI-005 & 훈련 \\
\hline & & MLQP-17 & 시설 및 환경조건 & MLQI-100 & 검사실 목록 \\
\hline & & & & MLQI-1XX & OO검사실(특수 환경 중심) \\
\hline & & MLQP-18 & 시험기관 장비 & MLQI-200 & 검사 장비 목록 \\
\hline & & & & MLQI-201 & 검사 장비 인수시험과 관리 \\
\hline & & & & MLQI-2XX & $\mathrm{OO}$ 검사 장비 \\
\hline & & MLQP-19 & 시험기관 시약 및 소모품 & MLQI-300 & 검사 시약 및 소모품 목록 \\
\hline & & & & MLQI-301 & 검사 시약 및 소모품 인수시험과 관리 \\
\hline & & & & MLQI-3XX & OO검사 시약 및 소모품 \\
\hline & & MLQP-20 & 검사 전 프로세스 & MLQI-006 & 1차 시료 채취 및 취급 \\
\hline & & & & MLQI-007 & 시료 운송 및 접수 \\
\hline & & & & MLQI-008 & 폐기물 처리 \\
\hline & & MLQP-21 & 검사 프로세스 & MLQI-400 & 검사 방법 목록 \\
\hline & & & & MLQI-4XX & $\mathrm{OO}$ 검사 \\
\hline & & & & MLQI-009 & 검사 방법 유효화 \\
\hline & & MLQP-22 & 검사 결과의 품질 보장 & MLQI-010 & 정도관리 \\
\hline & & & & MLQI-011 & 시험기관 간 비교 \\
\hline & & & & MLQI-012 & 측정불확도 \\
\hline & & & & MLQI-013 & 소급성 \\
\hline & & MLQP-23 & 검사 후 프로세스 & MLQI-014 & 결과 검토 \\
\hline & & & & MLQI-015 & 임상시료 보관, 보유 및 처리 \\
\hline & & MLQP-24 & 결과 보고 & MLQI-5XX & $\mathrm{OO}$ 검사 보고서 \\
\hline & & MLQP-25 & 결과 배포 & MLQI-016 & 결과 자동 선택 및 배포 \\
\hline & & MLQP-26 & 시험기관 정보관리 & MLQI-017 & 검사 정보 시스템 관리 \\
\hline
\end{tabular}

ISO 15189에서 규정하는 문서관리 절차는 먼저 발행에 앞서 권 한을 가진 책임자에 의해 검토되고 승인되어야 하며 모든 문서가 제목, 각 쪽의 고유한 식별표시, 최신본의 날짜 및 판수, 전체 쪽수 에 대한 쪽수, 발행 권한 등을 포함하여 식별되어야 한다. 또한 문서 관리대장을 작성하여 승인된 최신본, 최신본의 배포상황이 목록으 로 구별되어야 하며, 발행시점에서는 승인된 최신본만이 획득 가능 해야 하며 폐기된 문서의 사용이 배제되어야 한다. 폐기된 관리문 서에는 날짜를 기입하고 폐기라는 표시를 하여 최소한 사본 한 부
를 규정된 기간 또는 해당 규정 요구사항에 따라 보관한다. 수기에 의한 문서 수정이 필요한 경우 수기수정 절차와 권한이 규정되어야 하며 수정사항이 분명히 표시되고 서명, 날짜가 기입되어야 한다.

\section{4. 메디컬시험기관의 품질경영시스템에서 부적합 관리}

ISO 9001에서는 '부적합은 요구사항을 충족하지 않고 있는 것', '시정조치는 도출된 부적합 또는 바람직하지 않은 상황의 원인을 제거하기 위하여 적용되는 조치', '예방조치는 일어날 수 있는 부적 
합 또는 일어날 수 있는 바람직하지 않은 상황의 원인을 제거하기 위하여 적용되는 조치' 및 '지속적 개선은 요구 사항을 만족시키기 위한 능력을 증가시키기 위한 반복 활동'이라고 정의되어 있다[8]. 다른 요구사항들과 마찬가지로 시험기관은 품질경영시스템 전체 부분에 대하여 부적합을 파악하고 관리하기 위한 문서화된 절차를 요구하고 있으며, 문서화된 절차에서 보장해야 할 항목들을 아래와 같이 기술하고 있다. 검사 전, 검사 또는 검사 후 프로세스를 포함한 품질경영시스템의 전 부문에서 부적합을 파악 및 관리하기 위하여 시험기관은 문서화된 절차를 갖추어야 하며, 그 절차는 다음 사항 들을 보장하여야 한다.

a) 부적합을 취급하기 위한 책임 및 권한 지정

b) 시행할 즉시 조치 규정

c) 부적합의 정도 결정

d) 필요한 경우 검사를 중지하고 보고서를 제공하지 않음

e) 부적합한 검사의 임상적 의의를 고려하고, 해당될 경우 검사 를 의뢰한 임상의 또는 결과를 사용할 책임이 있는 승인된 사 람에게 통보

f) 필요한 경우 이미 보고된 부적합한 또는 잠재적으로 부적합한 검사 결과를 회수하거나 또는 이것을 적절히 식별

g) 검사 재개를 승인하는 책임을 규정

h) 각 부적합 사례를 문서화하고 기록하며, 이들 기록을 시험기 관 관리자가 정기적으로 검토하여 경향을 파악하고 시정조치 를 취함

부적합한 검사 또는 업무는 여러 분야에서 발생하며, 임상의의 불만, 내부 정도관리, 장비 보정, 소모품 점검, 시험기관간 비교, 직 원 의견, 보고 및 증명 확인, 시험기관 경영검토와 내부 및 외부 심사 를 포함한 다양한 방식으로 파악할 수 있다. 검사 전, 검사 및 검사 후 프로세스에서 부적합한 검사가 반복되거나 혹은 품질매뉴얼에 명시된 절차를 따르지 않을 우려가 있을 경우, 근본 원인을 파악, 문 서화 및 제거하는 절차를 즉시 시행하여야 한다. 조치할 시정조치 를 결정 및 문서화하여야 한다. 즉, 시험기관은 부적합 업무가 검출 된 경우 또는 시험 - 보정결과가 요구사항을 충족하지 않는 경우에 대처하는 방침 및 순서를 문서화하여야 한다. 먼저 부적합을 취급 하기 위한 책임 및 권한이 지정되어야 하며 부적합이 발견된 시점 에서 시행할 즉시 조치를 규정하여야하며 부적합의 정도를 결정하 여 필요한 경우 검사 중지 및 보고서 제공 중단을 시행하여야한다.

부적합한 검사의 임상적 의의에 따라서 검사 의뢰자(임상의) 또 는 결과를 사용할 책임이 있는 자에게 통보해야 하며, 이미 보고된 부적합 또는 잠재적 부적합한 검사결과를 회수하거나 식별하는 절 차를 수행해야 한다. 부적합 사항을 해결하고 나면 누가 어떻게 검 사 재개를 승인할 것인지 책임을 규정하여야 하며 파악된 부적합
사례는 문서화하고 기록하여 시험기관 관리자에 의해 정기적으로 검토되고 경향을 파악하여 적절한 시정조치가 취해져야 한다. 시정 조치는 당면한 부적합의 영향에 대하여 적절하여야 하며, 시험기관 은 부적합의 원인을 제거하는 예방조치를 취할 수 있다. 시험기관 은 시정조치에 대한 다음과 같은 문서화된 절차를 갖추어야 한다.

a) 부적합의 검토

b) 부적합의 근본 원인 결정

c) 부적합이 재발하지 않음을 보장하기 위한 시정조치의 필요성 에 대한 평가

d) 필요한 시정조치의 결정 및 실행

e) 취해진 시정조치의 결과 기록

f) 취해진 시정조치의 효과성 검토

일반적으로 부적합의 직접 영향을 경감하기 위하여 부적합이 발 생한 시점에 취해진 조치는 '즉시' 조치로 간주한다. 부적합을 일으 키는 문제의 근본 원인을 제거하기 위하여 취해진 조치만을 '시정' 조치로 간주한다. 시정조치는 부적합 원인을 제거하기 위해 취해지 는 행위이다. 일반적으로 '수정(remediation)'이라는 용어는 특정 한 사고와 관련된 문제의 수정이며 '시정조치(corrective action)' 는 그런 종류의 사고의 재발방지를 의미하고 있다. '예방조치 (preventive action)'는 가능성이 있는 것으로 판단된 부적합이나 과오를 방지하기 위하여 취해지는 조치를 의미한다. 따라서 시정조 치는 수정으로 끝나서는 안 되며, 그 사고의 잠재원인을 발견하는 것이 중요하므로 잠재 원인을 파악하고, 시정하는 것이 예방조치를 한 것이 된다는 점을 유념하여야한다. 이러한 시정조치의 절차 즉, 부적합 검토, 근본원인 결정, 시정조치 필요성 평가, 시정조치 결정 및 실행, 시정조치의 결과, 시정조치 효과에 대하여 문서화할 것을 요구하고 있다.

\section{5. 메디컬시험기관의 품질경영시스템에서 내부 심사 및 지속적 개선}

시험기관은 검사 전, 검사 및 검사 후 프로세스를 포함한 품질경 영시스템의 모든 활동이 표준의 요구사항 및 시험기관이 수립한 요 구사항에 적합하게 실행하고, 효과적으로 유지되고 있는 지에 대한 여부를 결정하기 위하여 계획된 주기로 내부 심사를 수행하여야 한 다. 통상적으로 내부심사 주기는 보통 일년 이내로 수행하는 것이 좋다. 내부심사에서는 매년 품질경영시스템의 모든 요소들을 세부 적으로 살펴볼 필요는 없다. 시험기관은 다른 사항을 완전히 무시 함이 없이 특정 활동에 중점을 두도록 결정해도 된다. 내부 심사는 품질경영시스템의 관리 및 기술 프로세스의 성과를 평가하도록 훈 련된 조직원이 수행하여야 한다. 심사 프로그램은 이전 심사의 결 과뿐만 아니라 프로세스의 상태 및 중요성과 심사할 기술 및 관리 
분야를 고려하여야 한다. 심사 기준, 범위, 빈도 및 방법을 규정하고 문서화하여야 한다. 심사원의 선정 및 심사 수행은 심사 프로세스 의 객관성 및 공평성을 보장하여야 한다. 자원이 허용하는 경우에 는 심사원은 심사 활동과 관계가 없어야 한다. 시험기관은 심사 계 획 및 수행과 결과 보고 및 기록 유지에 대한 책임과 요구사항을 규 정하는 문서화된 절차를 갖추어야 한다. 심사 받는 분야를 책임지 는 직원은 부적합이 파악 되었을 경우 적절한 조치를 즉시 수행함 을 보장하여야한다. 검출된 부적합의 원인을 제거하기 위하여, 부 당하게 지연하지 않고 시정조치를 수행하여야 한다.

아래 요구사항은 시험기관이 내부심사를 계획하고 내부심사직 원을 선정하고 심사를 수행하며 심사결과를 기록하는 과정에서의 요구사항을 기술하고 있다. 먼저 내부심사는 품질경영시스템의 모 든 활동이 ISO 15189 의 요구사항 및 시험 기관이 수립한 요구사항 에 적합하게 실행되고 있는지, 효과적으로 유지되고 있는 지를 결 정하기 위한 목적으로 계획되어야 하며 일반적으로 1 년의 주기로 시행할 것을 권장하고 있다[12].

a) 내부심사를 실시하는 자는 적절한 교육 - 훈련을 받아야한다.

b) 내부심사를 실시한 증거로 내부심사원 임명서, 내부심사 실 시계획서, 감사보고서, 부적합 보고서 등의 기록을 확인할 수 있어야 한다.

c) 내부심사의 심사계획 및 수행, 결과 보고, 기록 유지에 대한 책 임과 요구사항에 대한 문서화된 절차를 갖추어야 한다.

시험기관은 품질방침 및 품질목표에 명시한 바와 같이 평가 활 동에서 시험기관의 실제 성과를 비교하기 위한 경영검토와 시험기 관의 의지를 담은 예방조치와 시정조치를 통하여 검사 전, 검사 및 검사 프로세스를 포함한 품질경영시스템의 효과성을 지속적으로 개선하여야 한다. 개선활동은 위험 평가를 근거로 우선순위가 높은 분야를 지향하여야하며, 해당될 경우 개선 실행 계획을 개발, 문서 화 및 실행을 추진하여야 한다. 관련 분야의 집중 검토 또는 심사를 통해 취해진 조치의 효과성에 대한 평가가 필요하다.

시험기관 경영진은 시험기관이 환자 진료 해당 분야 및 성과를 포함하는 지속적인 개선 활동에 참여함을 보장해야 한다. 지속적인 개선 프로그램이 개선 기회를 파악한 경우 시험기관 경영진은 개선 기회가 발생하는 분야에 무관하게 개선 기회를 중점적으로 다루어 야한다. 시험기관 경영진은 직원들과 개선계획 및 관련 목표를 의 사소통 하여야 한다. 품질경영시스템의 통합성은 목표 달성을 위한 세부 요소들의 상호작용 즉, Plan-Do-Check-Act (P-D-C-A) cycle이 서로 유기적으로 작용하여 지속적인 개선(improvement) 이 이루어짐을 의미한다(Fig. 1). 이 요구사항은 이른바 P-D-C-A cycle이라 불리는 관리 시스템의 항상적 진보를 의도한 것이다. 시 정조치, 예방조치, 경영평가를 계속함으로써 지속적인 개선이 이
루어진다[13].

\section{6. 우리나라에서 메디컬시험기관 ISO 15189 의 도입 및 현재}

우리나라에서 메디컬시험기관 ISO 15189 인증에 대한 공식적 인 논의는 2009년 12월 지식경제부 기술표준원과 보건복지가족 부 질병관리본부 사이에 의료분야한국인정기구(Korea Laboratory Accreditation Scheme, KOLAS) 운영의 업무협력을 위한 양해각 서를 체결하면서 시작되었다. 의료기관에서 시행하는 혈액, 세포, 유전자에 대한 시험 - 분석이 국제표준에 따라 실시되고 그 결과에 대한 신뢰성도 국제적으로 인정받는 제도가 신설되었음을 공지하 면서, 정부는 의료 시험분석에 대한 문서관리, 전문시험인력과 장 비를 국제표준(ISO 15189)에 적합한 시험인정제도를 시행하여 국 제공인 시험성적서를 발행하기로 발표하였다. 정부는 우선 2010 년 상반기에 대형 병원과 전문 수탁시험 - 분석기관의 혈액, 소변검 사 등을 중심으로 의료인정제도를 시범운영하고, 문제점 보완 등을 거쳐 2010년 하반기부터 유전자, 진단검사 등 10여개 분야 1,000 여개 세부항목까지 300 여 병원을 대상으로 확대할 계획으로, 상반 기 시범운영 기간 내에 설명회 개최 등을 통한 인정제도 활성화와 국제기구(Asia Pacific Laboratory Accreditation Cooperation, APLAC; International Laboratory Accreditation Cooperation, ILAC)가입 준비도 병행하여 34개국과 공인시험성적서를 상호 인 정하는 체계를 마련할 예정이었다.

정부의 설명에 의하면 ISO 15189 제도는 국제표준에 따라 문서, 인력, 검사장비를 운용함으로써 의료검사 결과의 신뢰성이 높아지 고, 중복검사에 따른 시간과 비용절약 효과 및 오진률 감소도 기대 된다고 밝히고, 캐나다의 경우 ISO 15189 도입으로 오진률을 15 $20 \%$ 정도 감소시켰다고 소개하였다(2009년, ILAC 총회보고). 또 한, ISO 15189 Global Standard 인정체계 도입은 고부가가치 의 료 서비스 산업의 핵심 소프트 인프라를 구축하여 국내 의료검사 결과를 국제적으로 인정받게 됨으로써 국내 의료산업의 수출 성과 를 크게 향상시키는 계기가 될 것으로 기대하였다.

그러나 정부의 ISO 15189 추진 계획은 다소 지연되어 메디컬시 험기관 국제 공인제도가 국내에 도입된 것은 2005년이고, 서울대 병원 - 삼성서울병원 등 국내 8개 대학병원(핵의학 - 병리학분야 12개 검사실)이 메디컬시험기관 시범인정(2010 2011년)을 받 기도 했지만, 국제 공인제도에 대한 홍보가 제대로 이뤄지지 않아 병원들은 ISO 15189 인정이 있는지 조차 모르고 있는 실정이었다. 또 병원들이 의료기관평가인증, JCI 인증(Joint Commission International) 등을 통해 검사실에 대한 부분도 인증을 받고 있어 ISO 15189 까지 인정을 받으려면 이중 삼중의 고통이 따르는 문제 때문에 외면을 받았었다. 정부에서는 이러한 문제점을 해결하기 위 
해 산업통상자원부는 보건복지부, 의료기관인증평가원 등과 협의 를 통해 병원이 검사실에 대해 ISO 15189 인정을 받은 경우 인증평 가 항목에서 검사실 분야를 제외시켜주는 방안을 논의하기도 하였 다. 2014년 7월 국가기술표준원은 그간 국제표준에 적합한 메디컬 시험기관 인정 제도 도입을 위해 의료관련 학회, 단체, 그리고 분야 별 전문가와 협력해 인정제도 실시를 위한 인프라 구축을 마무리했 다고 발표하였다. 또한, 핵의학과 병리학분야의 검사실 평가기준 인 추가기술요건 8종을 제정하고, 메디컬분야 인정분류체계와 인 정제도 운영요령 개정 등을 통해 제도운영에 대한 준비를 완료했다 고 말했다. 이와 함께 검사실의 인력과 평가사 교육을 위한 커리큘 럼 개발 후 메디컬분야 KOLAS 교육을 실시하고, 병리학과 핵의학 분야의 숙련도프로그램을 개발 - 실시하고 있다고 덧붙여 국내 메 디컬시험기관에 실제적인 ISO 15189의 도입이 멀지 않았음을 알 수 있다.

정부의 ISO 15189 추진 의지 표명 직후, 삼성서울병원이 국내 의료기관 중 최초로 2014년 8월에 '메디컬서비스 국제표준 ISO 15189 인정'을 획득했다고 발표하였다. 삼성서울병원 핵의학검사 실은 한국인정기구(KOLAS)로부터 호르몬 검사, 종양표지자검사, 간염검사, 기타외 검사 등 4 개 분야 - 47 개 항목에 대한 국제표준 ISO 15189를 인정 받았다고 밝혔었다. ISO 15189 인정 획득을 계 기로 삼성서울병원은 핵의학검사를 포함한 병원 내에서 이뤄지는 각종 검사의 신뢰 수준을 획기적으로 끌어올릴 수 있을 것으로 기 대하고 있으며, 특히, ISO 15189 가 세계 각국에서 통용되는 국제 표준인 만큼, 검사의 객관성과 신뢰성을 담보할 수 있어 앞으로 해 외환자 유치 확대에도 큰 도움이 될 것으로 기대한다고 하였다.

이러한 정부의 의지와 대형 의료 기관의 선제적인 ISO 15189 의 도입에도 불구하고 일선 의료기관과 검사센터에서 ISO 15189의 도입을 아직까지 지연하고 있는 상황이다. 그러나 한국인정기구 (KOLAS)는 이미 메디컬시험기관의 품질 및 적격성에 대한 ISO 15189 인증 평가 시스템 구축이 완료되었으며, 이에 대한 심사자 교육도 마무리되었다고 보고한 상태이다. 이러한 한국인정기구 (KOLAS)에서 명시하고 있는 메디컬시험기관 인정제도와 관련된 관련법 및 기준은 아래와 같다.
a) 국가표준기본법
b) 국가표준기본법시행령
c) 공인메디컬시험기관 인정제도운영요령(KS P ISO 15189:2013)
d) 공인기관인정 신청 및 평가 수행 절차에 관한 규정
e) 분야별 추가기술 요건
f) 측정 결과의 소급성 유지를 위한 지침
g) 측정 결과의 불확도 추정 및 표현을 위한 지침
h) 숙련도시험 운영 기준

i) 인정마크 사용 및 국제공인기관 표시를 위한 지침

j) KOLAS 메디컬분야 평가사와 기술전문가의 자격 및 등록에 관 한 운영 요령

k) KS Q ISO/IEC 17011 : 적합성평가 - 인정기관에 대한 일반 요구 사항

1) GUM:1995, 측정불확도 표현 지침(ISO, IEC, BIPM, IFCC, IUPAC, IUPAP and OIML)

따라서 현 시점에서 메디컬시험기관에 대한 ISO 15189 의 도입 은 더 이상 지연될 수 없는 상황이므로, 일선의 의료기관과 검사센 터들도 단계적으로 ISO 15189 인증을 준비하는 것이 필요한 시기 이다. 기존에 ISO 9001과 같은 품질경영시스템을 운영하였던 기 관들은 다소 수월하게 ISO 15189 도입이 가능하지만, ISO 경험이 전무한 기관들에서는 도입 준비에 상당한 기간이 소요될 것으로 예 상된다. 이러한 ISO 15189 도입의 궁극적인 목적은 메디컬 서비스 의 질적 수준의 향상과 국제적인 경쟁력 강화이므로, 각 기관에서 는 능동적인 자세로 도입 준비에 힘써야 할 것으로 생각된다.

\section{결 론}

인간 질병의 진단, 관리, 예방 및 치료에 대한 정보를 제공하거나 혹은 건강 상태를 평가하기 위해 인체로부터 유래한 검체의 생물 학, 미생물학, 면역학, 화학, 생화학, 면역혈액학 혈액학, 생리학, 세 포학, 병리학, 유전학 또는 기타 검사를 수행하고, 결과의 해석과 적 절한 추가 조사에 대한 권고를 포함하여 모든 시험 기관의 조사측 면에서 자문 서비스를 제공할 수 있는 시험기관을 ISO 15189의 대 상인 메디컬시험기관으로 정의한다[11,12]. 메디컬시험기관이라 는 용어의 정의는 ISO 15189 표준을 적용하는 대상을 규정하는 것 으로서 매우 중요한 의미를 담고 있다. 메디컬시험기관 ISO 15189 인정제도는 법률 또는 국제기준에 적합한 인정기구가 전문적인 자 격을 갖춘 평가사로 하여금 메디컬시험기관의 품질 시스템과 기술 능력을 평가하도록 하여 메디컬시험 분야에 대한 시험능력이 있다 는 것을 공식적으로 인정하는 제도로 우리나라에서는 한국인정기 구(KOLAS)가 담당하고 있다. 따라서 각 기관은 작업내용의 실태를 파악하여 ISO 15189 가 규정하는 업무에 해당하는지를 판단한 후 인정 신청을 하거나 평가를 받을 수 있다(Fig. 3). 우리나라의 경우 진단검사의학, 병리학, 핵의학, 공중보건의학 관련 검사실 및 검사 센터를 포함한다.

메디컬시험기관 서비스의 목적은 고객(환자, 임상의 등)의 요구 에 따르는 것이다. 이 조항은 ISO 9001 품질경영 시스템의 조항 중 에서 중점을 두고 있는 '품질경영 8원칙' 중의 '고객중시'를 나타내 고 있다. 참고적으로 품질경영의 8원칙은 다음의 것을 가리킨다: 


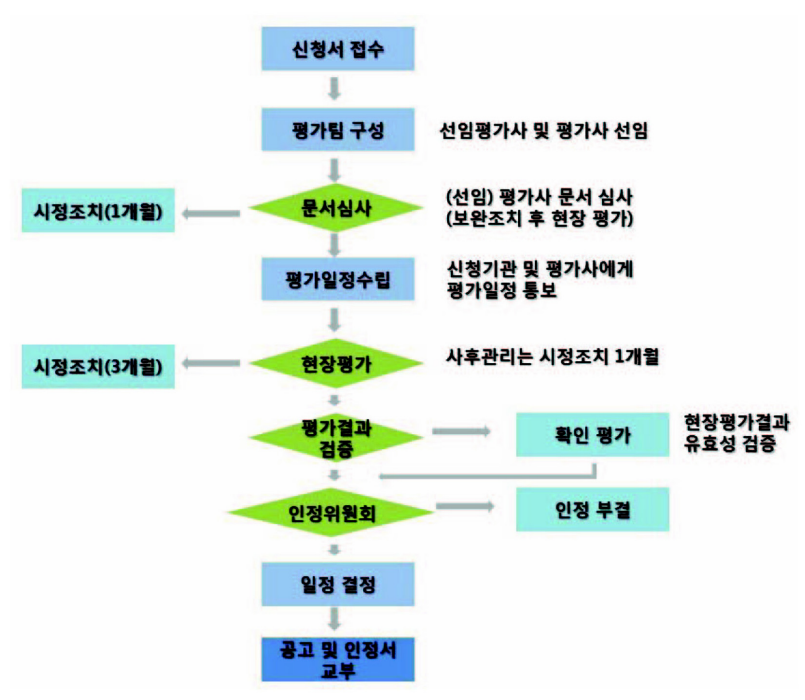

Fig. 3. Process of KS P ISO 15189:2013 accreditation in KOLAS.

고객중시, 리더십, 직원의 참여, 프로세스 접근, 경영에 대한 시스 템 접근, 지속적 개선, 의사결정에 대한 사실에 의한 접근, 공급자와 의 호혜관계 등. 시험기관은 품질방침 중에서 시험기관 서비스의 목적으로서 '환자 및 환자진료에 책임을 가진 사람의 요구에 부응 하는 것'을 명확히 하여야 한다. 예를 들면 메디컬시험기관은 검사 데이터를 제공하는 것뿐만 아니라 검사결과들 간의 일관성이나 생 물학적 기준범위에 비춰 정상인지 여부를 판정하는 서비스도 제공 할 수 있어야 한다. 또한, 그 국가의 법에 따르는 범위에서 적절한 해 석 및 조언 서비스까지를 포함시키는 것이 이상적이다. 품질경영시 스템의 통합성은 목표 달성을 위한 세부 요소들의 상호작용 즉, Plan-Do-Check-Act (P-D-C-A) cycle이 서로 유기적으로 작용 하여 지속적인 개선(improvement)이 이루어짐을 의미한다. 이 요 구사항은 이른바 P-D-C-A cycle이라 불리는 관리 시스템의 효과 적인 운영을 위해 시정조치, 예방조치, 경영평가를 주기적으로 진 행함으로써 지속적인 개선이 이루어진다[13,14]. 또한, 최근에는 품질경영 운영 프로세스의 품질을 정량화하기 위한 품질 지시자 (quality indicators)를 도입하여, 검사데이터의 안전성과 정확성 을 식별하고 효과적인 개입을 구현하여 지속적으로 결함을 모니터 링하고 개선하는 방법이 제시되기도 하였다[15]. 이러한 장점들을 활용하기 위한 정부의 2010년 무렵의 도입 계획은 다소 지연되었 지만, ISO 15189 도입의 궁극적인 목적인 메디컬 서비스의 질적 수 준의 향상과 국제적인 경쟁력 강화에 대한 사회적인 요구를 반영하 기 위해, 각 기관에서는 적극적인 자세로 도입에 노력해야 할 것으 로 생각된다. 2016년 4월 1일 기준으로 한국인정기구(KOLAS)를 통해 KS P ISO 15189:2013 메디컬시험기관 인정 기관은 공공기 관 2곳과 민간기관이 3곳으로 공시되어 있다(Table 3). 인정분야로
Table 3. List of accreditation number, laboratory name and period by KOLAS

\begin{tabular}{clc}
\hline 인정번호 & \multicolumn{1}{c}{ 기관명 } & 공인유효기간 \\
\hline $\mathrm{KM} 001-1$ & 삼성서울병원 핵의학과 & $2014-08-25 \sim 2016-08-24$ \\
$\mathrm{KM} 002-1$ & 한국원자력의학원 & $2014-12-22 \sim 2016-12-21$ \\
& 생물학적선량평가실 & \\
$\mathrm{KM} 003-1$ & 서울아산병원 핵의학과 & $2015-05-26 \sim 2017-05-25$ \\
$\mathrm{KM} 003-2$ & 서울아산병원 병리과 & $2015-12-04 \sim 2017-12-03$ \\
$\mathrm{KM} 004-1$ & 서울대학교병원 핵의학과 & $2015-05-26 \sim 2017-05-25$ \\
\hline
\end{tabular}

는 진단검사의학-세포유전검사 1 곳, 핵의학-호르몬 검사 3 곳, 핵 의학-종양표지검사 3 곳, 핵의학-종양표지검사 3 곳, 핵의학-기타 외시험 3 곳, 병리학-조직병리진단 1 곳, 병리학-세포병리진단 1 곳, 병리학-특수병리진단 1곳으로 고시되어 있다.

\section{요 약}

다양한 분야에 대한 품질표준들 중에서 메디컬시험기관에 대한 품질 및 적격성에 대한 요구사항인 ISO 15189는 ISO 9001; 품질 경영시스템-요구사항과 ISO/IEC 17025; 시험기관 및 교정기관의 능력에 관한 일반요구사항인 두 표준을 바탕으로 메디컬시험기관 에 요구되는 사항들을 충족하도록 제정되어 있다. 이 ISO 15189에 서는 메디컬시험기관 검사에 관여하는 실무자의 자격 및 지속적인 역량, 시험기관 규모, 장비, 시약 및 소모품, 분석전 및 분석인자, 품 질보증을 위한 고려사항 및 분석 후 인자 등이 기술되어 있다. 인정 과정에서는 업무와 관련된 범주에 전문성을 갖춘 전문가 및 임상 평가사들은 다음의 사항을 포함하여 시험데이터 산출에 영향을 미 치는 시험기관에서의 모든 요인에 대한 철저한 평가를 수행한다. 메디컬시험기관의 품질경영시스템은 임상의 또는 환자의 니즈 및 요구사항을 충족시켜야 한다. 품질경영시스템을 기획할 때는 요구 사항을 준수하고 품질목표를 충족시켜야 하며 변경하고자 하는 경 우에는 품질경영시스템의 통합성을 유지시켜야 한다. 품질경영시 스템의 통합성은 목표 달성을 위한 세부 요소들의 상호작용 즉, Plan-Do-Check-Act (P-D-C-A) cycle이 서로 유기적으로 작용 하여 지속적인 개선(improvement)이 이루어짐을 의미한다. 메디 컬시험기관 ISO 15189 인정제도는 법률 또는 국제기준에 적합한 인정기구가 전문적인 자격을 갖춘 평가사로 하여금 메디컬시험기 관의 품질 시스템과 기술능력을 평가하도록 하여 메디컬시험분야 에 대한 시험능력이 있다는 것을 공식적으로 인정하는 제도로 우리 나라에서는 한국인정기구(KOLAS)가 담당하고 있다. 정부의 2010 년 무렵의 KS P ISO 15189 도입 계획은 다소 지연되어, 2016년 4 월 1 일 기준으로 한국인정기구(KOLAS)를 통해 인정 받은 메디컬 시험기관은 공공기관 2곳(한국원자력의학원 생물학적선량 평가 
실, 서울대학교병원 핵의학과)과 민간기관이 3곳(삼성서울병원 핵 의학과, 서울아산병원 핵의학과, 서울아산병원 병리과)뿐이지만, ISO 15189 도입의 궁극적인 목적인 메디컬 서비스의 질적 수준의 향상과 국제적인 경쟁력 강화에 대한 사회적인 요구를 반영하기 위 해, 각 기관에서는 적극적인 자세로 도입에 노력해야 할 것으로 생 각된다.

\section{Acknowledgements: None}

Funding: None

Conflict of interest: None

\section{References}

1. International Organization for Standardization. About ISO [cited 2016 April 01]. Available from: http://www.iso.org/iso/ home.htm

2. International Organization for Standardization. ISO members [cited 2016 April 01]. Available from: http://www.iso.org/ iso/home/about/iso_members.htm

3. International Organization for Standardization. ISO standards [cited 2016 April 01]. Available from: http://www.iso.org/ iso/home/standards.htm

4. Van der Wiele A, Dale BG, Williams ART. ISO 9000 series registration to total quality management the transformation journey. Int J Qual Sci. 1997;2:236-252.

5. Conti T. Vision 2000: positioning the new ISO 9000 standards with respect to total quality management models. Total Qual Manag. 1999;10:454-464.
6. Van der Wiele A, Dale BG, Williams ART. Business improvement through quality management systems. Manag Decis. 2000; 38:19-23.

7. Van der Wiele A, Williams ART, Brown A, Dale BG. The ISO 9000 series as a tool for organizational change. Busin Proc Manag J. 2001;7:323-331.

8. International Organization for Standardization. ISO 9001:2008 Quality management systems - Requirements [cited 2016 April 01]. Available from: http://www.iso.org/iso/catalogue_detail? csnumber $=46486$

9. Tsim YC, Yeung VWS, Leung, ETC. An adaptation to ISO 9001: 2000 for certified organizations. Manag Audit J. 2002;17:19-23.

10. Wilkinson G, Dale BG. An examination of the ISO 9001:2000 standard and its influence on the integration of management systems. Prod Plan Contr. 2002;13:284-297.

11. International Organization for Standardization. ISO 15189:2003. Medical laboratories - Particular requirements for quality and competence [cited 2016 April 01]. Available from: http:// www.iso.org/iso/catalogue_detail?csnumber $=42641$

12. Korean Standards Service Network. KS P ISO 15189:2013. Medical laboratories - Requirements for quality and competence [cited 2016 April 01]. Available from: http:// www.kssn.net/StdKS/ks_detail.asp?k1=P\&k2=ISO\%2015189\& $\mathrm{k} 3=3$

13. Burnett D. ISO 15189:2003 - Quality management, evaluation, and continual improvement. Clin Chem Lab Med. 2006;44: 733-739.

14. Plebani M. The detection and prevention of errors in laboratory medicine. Ann Clin Biochem. 2010;47:101-110.

15. Plebani M, Astion ML, Barth JH, Chen W, de Oliveira Galoro CA, Escuer MI, et al. Harmonization of quality indicators in laboratory medicine. A preliminary consensus. Clin Chem Lab Med. 2014;52:951-958. 